\title{
Correction to: ARoCuS Web application promotes standardized treatment and documentation of rotator cuff tears
}

\author{
S. G. Walter ${ }^{1} \oplus$ - D. Cucchi ${ }^{1} \cdot$ W. Thomas ${ }^{2} \cdot$ M. J. Friedrich ${ }^{1} \cdot$ T. Jansen $^{1}$
}

Published online: 24 June 2021

(c) The Author(s) 2021

\section{Correction to: MUSCULOSKELETAL SURGERY https://doi.org/10.1007/s12306-020-00658-8}

The article ARoCuS Web application promotes standardized treatment and documentation of rotator cuff tears, written by S. G. Walter, D. Cucchi, W. Thomas, M. J. Friedrich and T. Jansen, was originally published electronically on the publisher's internet portal on 20 April 2020 without open access. With the author(s)' decision to opt for Open Choice the copyright of the article changed on 26 May 2021 to () The Author(s) 2021 and this article is licensed under a Creative Commons Attribution 4.0 International License, which permits use, sharing, adaptation, distribution and reproduction in any medium or format, as long as you give appropriate credit to the original author(s) and the source, provide a link to the Creative Commons licence, and indicate if changes were made. The images or other third party material in this article are included in the article's Creative Commons licence, unless indicated otherwise in a credit line to the material. If material is not included in the article's Creative Commons licence and your intended use is not permitted by statutory regulation or exceeds the permitted use, you will need to obtain permission directly from the copyright holder. To view a copy of this licence, visit http://creativecommons. org/licenses/by/4.0/.

The original article has been corrected.

The original article can be found online at https://doi.org/10.1007/ s12306-020-00658-8.

S. G. Walter

sebastianwalter01@gmail.com

1 Department for Orthopedic Surgery, University Hospital, 53127 Bonn, Germany

2 Clinic for Orthopedic Surgery, Karol Wojtyla Hospital, Viale Africa 32, 00144 Rome, Italy
Funding Open Access funding enabled and organized by Projekt DEAL.

Open Access This article is licensed under a Creative Commons Attribution 4.0 International License, which permits use, sharing, adaptation, distribution and reproduction in any medium or format, as long as you give appropriate credit to the original author(s) and the source, provide a link to the Creative Commons licence, and indicate if changes were made. The images or other third party material in this article are included in the article's Creative Commons licence, unless indicated otherwise in a credit line to the material. If material is not included in the article's Creative Commons licence and your intended use is not permitted by statutory regulation or exceeds the permitted use, you will need to obtain permission directly from the copyright holder. To view a copy of this licence, visit http://creativecommons.org/licenses/by/4.0/.

Publisher's Note Springer Nature remains neutral with regard to jurisdictional claims in published maps and institutional affiliations. 